\title{
Model Penilaian Risiko Berbasis Kinerja untuk Rantai Pasok Kelapa Sawit Berkelanjutan di Indonesia
}

\author{
Rika Ampuh Hadiguna ${ }^{1^{*}}$
}

\begin{abstract}
As the country's largest palm oil producer in the world, Indonesian palm oil production is still encounter political barriers or non-tariff economy of several countries. Sustainable development policies have a role to overcome these obstacles. The research problem is how to build policies through the performance based risk assessment for sustainable palm oil supply chain in Indonesia. The research objective is to recommend policies that supported by performance-based risk assessment models for sustainable palm oil supply chain in Indonesia. Performance-based risk assessment algorithms have been developed and verified in a comprehensive manner. Model verification is conducted by analyzing the performance of crude palm oil supply chain based on expert's analysis. This study has obtained the necessary indicators to assess the risk based on performance of sustainable crude palm oil supply chain. Model application has shown that risk level of sustainable crude palm oil in Indonesia relating to economics, environmental, and social aspects are moderate, respectively. However, there are some indicators that need to be considered with the level of risk is quite high, namely demand rate, quality of palm oil, timelines of product delivery, availability of crude palm oil and bullwhip effect. This paper has recommended some policies to address those risks.
\end{abstract}

Keywords: Supply chain, palm oil, risk, performance, sustainable.

\section{Pendahuluan}

Manajemen rantai pasok minyak sawit (crude palm oil) yang fokus pada efektivitas operasional telah menjadi perhatian para peneliti seperti Djohar et al. [4], Hadiguna et al. [8, 10], Machfud [16]. Selanjutnya, isu keberlanjutan telah menjadi perhatian serius para pelaku industri minyak sawit. Isu keberlanjutan (sustainable) yang meliputi aspek lingkungan, aspek sosial dan aspek ekonomi telah menjadi isu strategis secara global. Menurut Beamon [1], isu keberlanjutan sangat penting dalam manajemen rantai pasok untuk menjamin keberlangsungan bisnis. Menurut Widodo [27] dan Widodo et al. [29], hal ini penting diperhatikan karena berkaitan dengan dampak dari kedinamisan, ketidakpastian, dan pertentangan tujuan ekologi, ekonomi, dan sosial.

Sebagai negara produsen minyak sawit terbesar di dunia, produksi minyak sawit Indonesia selalu mendapatkan hambatan politik ekonomi atau non tarif dari beberapa negara. Misalnya, Australia yang menetapkan Undang-Undang Food Standards Amandment (Truth in Labeling - Palm Oil) tahun 2011. Situasi ini menjadi ancaman terhadap daya saing minyak sawit produksi Indonesia (http://www. indonesiafinancetoday.com). Pemerintah mengelola ancaman ini dengan mengeluarkan standar kelestari-

\footnotetext{
1 Fakultas Teknik, Jurusan Teknik Industri, Universitas Andalas Limau Manis, Padang 25163, Indonesia.

Email: hadiguna@ft.unand.ac.id

*Penulis korespondensi
}

an minyak sawit Indonesia (Indonesian Sustainable Palm Oil, ISPO) pada Maret 2011. (http://health. kompas.com).

Risiko yang dipicu dari isu keberlanjutan perlu dikelola dengan baik untuk menjamin kontinuitas pasokan ke negara Eropa seperti Spanyol dan Perancis. Selama ini, Spanyol mengimpor kelapa sawit dan kedelai dari Argentina. Laporan Direktorat Jenderal Pengolahan dan Pemasaran Hasil Pertanian Kementerian Pertanian RI (http://pphp. deptan.go.id) menjelaskan bahwa ekspor minyak sawit Indonesia ke Uni Eropa, pada 2008 mencapai 4,36 juta ton dengan kisaran harga per ton US\$626 (US $\$ 2,73$ miliar) kemudian naik menjadi 4,79 juta ton dengan kisaran harga per ton US $\$ 454$ (US $\$ 2,16$ miliar) pada 2009 dan 4,06 juta ton pada 2010 dengan kisaran harga per ton berkisar US $\$ 643$ (US\$2,61 miliar). Salah satu hambatan ekspor ke Spanyol adalah penerapan EU Renewable Directive yang berpotensi sebagai hambatan non-tarif dalam perdagangan.

Uraian di atas menunjukan bahwa isu keberlanjutan merupakan situasi yang kompleks sehingga memicu munculnya risiko yang perlu dikelola secara sistematis. Kemunculan risiko tidak terlepas dari kinerja operasional yang berdampak pada tingkat strategis. Menurut Sabri dan Beamon [19], integrasi manajemen rantai pasok tingkat strategis dan operasional secara simultan sangat penting dilakukan. Di samping itu, risiko yang dipicu isu keberlanjutan memungkinkan terjadinya multi tafsir sebagaimana dinyatakan Blengini dan Shield [2], Carter dan 
Rogers [3], Sikdar [23]. Praktek rantai pasokan yang berkelanjutan patut memperhatikan beragam proses diantara pengadaan yang bertanggung jawab, pemantauan produk, etika organisasi, dan operasi berkelanjutan menurut Wagner dan Svensson [28].

Upaya menjawab permasalahan isu keberlanjutan dalam rantai pasok minyak sawit adalah penilaian risiko keberlanjutan dan mitigasinya. Beberapa studi sebelumnya antara lain tinjauan berbagai model kuantitatif untuk mengelola risiko rantai pasok diantaranya oleh Faisal [5] dan Tang [25], stabilitas kerjasama dinamis antar mitra dalam rantai pasok oleh Khan dan Burnes [14], pengaruh perubahan iklim terhadap keamanan produk pangan oleh Jacxsens et al. [13]. Berdasarkan beberapa studi tersebut, penilaian berfokus hanya pada prediksi kejadian yang mengganggu, bukan akar penyebab ketidakpastian yang dinyatakan oleh Trkman dan McCormack [24]. Dalam konteks rantai pasok minyak sawit, risiko ketidakpastian berkelanjutan bersumber dari aspek ekonomi, lingkungan dan sosial politik. Akar ketidakpastian dapat dideteksi melalui kinerja periode-periode saat ini atau sebelumnya.

Beberapa penelitian terdahulu belum mempertimbangkan hal ini. Penilaian risiko berbasis kinerja rantai pasok minyak sawit berkelanjutan menjadi kunci penting untuk setiap tingkatan keputusan. Para pengambil keputusan membutuhkan sebuah alat bantu dalam proses penilaian risiko berkelanjutan. Tujuan studi adalah membangun model yang berkemampuan melakukan penilaian risiko berbasis kinerja untuk rantai pasok minyak sawit berkelanjutan. Urgensi penelitian ini adalah kebutuhan terhadap sebuah alat analisis yang komprehensif untuk dimanfaatkan oleh pembuat kebijakan dalam pengelolaan sistem industri minyak sawit berkelanjutan.

\section{Sistem Rantai Pasok Minyak Sawit}

Supply chain management (SCM) atau manajemen rantai pasok minyak sawit merupakan salah satu sistem kompleks yang sangat menarik dipelajari. Manajemen rantai pasok minyak sawit belum banyak mendapatkan perhatian dari para peneliti. Dalam dekade terakhir, fokus para peneliti kelapa sawit lebih diarahkan pada pengembangan peralatan. Dari aspek budidaya, upaya yang terus menerus dilakukan adalah meningkatkan produktivitas. Hal ini tentunya perlu diiringi manajemen operasional yang handal sehingga produksi yang dihasilkan mampu memberikan manfaat bagi seluruh pihak yang berkepentingan. Ekonomi industri minyak sawit mentah masih menjadi perhatian utama para peneliti. Isu-isu yang terkait dengan manajemen risiko rantai pasok green belum banyak mendapatkan perhatian.

Hadiguna et al. [8] telah memperkenalkan sebuah model konseptual dari manajemen rantai pasok minyak sawit. Pada dasarnya, model koseptual ini menjelaskan aktivitas-aktivitas kunci dan keterkaitannya dalam sebuah sistem kordinasi rantai pasok. Aktivitas-aktivitas kunci tersebut membutuhkan tata kelola yang baik untuk mendapatkan praktik manajemen rantai pasok yang andal. Modelmodel dari beberapa aktivitas kunci tersebut yang telah dikembangkan antara lain Hadiguna dan Machfud [9] yang mengembangkan model perencanaan produksi minyak sawit. Model dikembangkan menggunakan fuzzy programa linear yang bermanfaat untuk optimasi produksi minyak sawit. Hadiguna [10] juga mengembangkan sebuah model persediaan minyak sawit di tangki timbun pelabuhan. Model ini bermanfaat untuk menjamin ketersediaan produk sesuai dengan jadwal kedatangan kapal. Pengembangan model dengan menerapkan fuzzy kuantitas ukuran ekonomis yang dimodifikasi. Lanjutan dari model persediaan ini adalah perancangan sistem pendukung keputusan yang dikembangkan oleh Machfud et al. [16]. Model ini sangat membantu pengambil keputusan dalam perencanaan dan pengendalian persediaan dalam rangka memenuhi tingkat pelayanan yang telah ditetapkan.

Penelitian lainnya yang membahas rantai pasok minyak sawit adalah Widodo et al. [29] yang mengembangkan model dinamika sistem dengan mempertimbangkan aspek pendapatan, kesejahteraan sosial dan lingkungan. Penelitian ini memberi perhatian terhadap kebijakan peningkatan produktivitas perkebunan dan dampaknya terhadap lingkungan. Widodo [27] juga membahas manajemen rantai pasok minyak sawit dengan mempertimbangkan keberadaan industri furnitur. Model ini dikembangkan menggunakan dinamika sistem untuk mendapatkan kondisi terbaik peningkatan produktivitas perkebunan kelapa sawit dengan memanfaatkan limbah kelapa sawit untuk bahan baku industri furnitur. Djohar et al. [4] juga mengembangkan model dinamika sistem untuk merumuskan skenario peningkatan daya saing minyak sawit melalui manajemen rantai pasok.

\section{Penilaian Risiko Kerberlanjutan}

Penilaian risiko rantai pasok merupakan bagian yang penting untuk menjamin kelangsungan bisnis. Dampak dari terjadinya risiko adalah kerugian baik dari sisi kehilangan pendapatan maupun pencitraan perusahaan atau produk yang menurun. Penilaian risiko menjadi penting untuk mengukur dampak yang akan terjadi dan perusahaan dapat mengantisipasinya. 
Tabel 1. Ringkasan studi penilaian risiko rantai pasok

\begin{tabular}{ll}
\hline \multicolumn{1}{c}{ Model } & \multicolumn{1}{c}{ Pembahasan } \\
\hline Formulasi matematik & Jaringan rantai pasok, temasuk \\
{$[12,21]$} & inventori, profit, dan biaya total \\
Simulasi $[6,26]$ & Kualitas dan kuantitas produk \\
Uji statistik $[7,15,30]$ & Analisa faktor-faktor risiko \\
\hline
\end{tabular}

Penelitian pengembangan metode penilaian risiko rantai pasok masih terus dilakukan dan umumnya memberi perhatian kepada penerapan metodemetode pengambilan keputusan kriteria majemuk. Perkembangan studi penilaian risiko rantai pasok dapat dikategorikan sustainable dan non-sustainable. Kategori sustainable artinya mempertimbangkan isu-isu keberlanjutan termasuk aspek ekonomi, sosial dan lingkungan. Non-sustainable hanya fokus pada aspek-aspek ekonomis seperti total biaya, mutu dan waktu.

Beberapa publikasi penilaian risiko rantai pasok green antara lain Sarkis penerapan analytical network process (ANP) untuk menilai risiko rantai pasok green oleh Sarkis [20]. Studi ini memperkenalkan atribut-atribut green supply chain yang bersifat umum untuk industry manufaktur dan menjelaskan cara kerja dari ANP. Studi lainnya adalah membangun sebuah metodologi penilaian risiko rantai pasok green menggunakan fuzzy AHP oleh Yang dan Li [32]. Studi yang telah dilakukan ini fokus pada cara penentuan prioritas dari jenis-jenis risiko rantai pasok green. Keunggulan dari studi ini hanya kemampuan penentuan prioritas tetapi belum teruji untuk penilaian risiko rantai pasok industri minyak sawit.

Studi penerapan ANP lainnya dalam penilaian risiko rantai pasok berdasarkan life cycle dari proses dan produk oleh Xia dan Chen [31]. Metode yang dikembangkan ini bertujuan untuk mendapatkan indikator-indikator kritikal dari operasional rantai pasok. Model matematik pemilihan pemasok dari sistem rantai pasok green dikembangkan oleh Yeh dan Chuang [33] untuk multi tahap dan setiap tahap melakukan proses pemilihan pemasok. Formulasi matematik diselesaikan menggunakan algoritma genetika. Ada empat indikator yang diformulasikan menjadi fungsi obyektif yaitu biaya total, waktu total, kualitas produk dan kepedulian lingkungan. Model ini untuk pemilihan pemasok melalui penanganan risiko dari setiap alterantif pemasok. Ringkasan beberapa studi penilaian risiko rantai pasok dapat dilihat pada Tabel 1.

Studi ini akan membahas sebuah konsep baru yaitu penilaian risiko berbasis kinerja. Penilaian risiko berorientasi pada periode akan datang, sedangkan pengukuran kinerja berorientasi pada periode masa lalu. Makalah pada beberapa studi sebelumnya menyajikan penilaian risiko dan pengukuran kinerja masing-masing secara berdiri sendiri (stand alone).

\section{Metode Penelitian}

Penelitian ini menggunakan pendekatan sistem dengan tahapan penelitian sebagai berikut: pertama, tahap pemahaman situasi nyata. Pada tahapan ini dilakukan studi lapang, pustaka dan diskusi perihal isu-isu keberlanjutan di industri kelapa sawit nasional.

Kedua, tahap identifikasi dan formulasi indikatorindikator berdasarkan tiga aspek yaitu ekonomis, lingkungan dan sosial politik. Proses ini dilakukan dengan cara berdiskusi dengan para akademisi, praktisi dan hasil-hasil penelitian yang relevan dengan isu minyak sawit berkelanjutan. Hasil identifikasi dijaring berdasarkan analisis logika. Proses ini dilakukan dengan mempelajari pengertian dari setiap indikator yang diperoleh dari pendapat para pakar. Tujuan penjaringan adalah menjamin tidak ada overlapping antar indikator dan pengelompokan berdasarkan tiga aspek keberlanjutan yang digunakan dalam studi ini.

Ketiga, tahap perumusan algoritma dan komputasi. Tahap ini bertujuan menghasilkan algoritma penilaian kinerja, penilaian risiko dan integrasinya. Algoritma diimplementasikan menggunakan bahasa program komputer MATLAB R2009b. Proses perhitungan yang digunakan dalam studi ini merujuk pada konsep non numeric multi criteria decision making oleh Yager [34]. Kinerja dinilai berdasarkan beberapa tingkatan, yaitu sangat baik, baik, cukup baik, biasa, kurang baik, sangat kurang baik, Buruk. Penilaian risiko juga menggunakan linguistik yang terdiri dari tingkatan, yaitu tidak ada dampak, sangat kurang berdampak, kurang berdampak, berdampak biasa, cukup besar dampaknya, besar dampaknya, sangat besar dampaknya.

Keempat, tahap pengumpulan data yang merupakan bagian dari proses verifikasi model. Pengumpulan data menggunakan kuesioner dan disebarkan kepada 15 orang pakar. Pakar dalam studi ini adalah orang yang mempunyai pengetahuan dan pengalaman baik secara akademik ataupun praktis di bidang industri kelapa sawit. Para pakar yang dihubungi berlatar belakang pendidikan S2 dan S3 dan punya pengalaman penelitian atau praktisi dibidang industri kelapa sawit.

Kelima, tahap analisis kebijakan. Proses ini dibangun melalui basis aturan yang menghubungkan 
antara nilai risiko dan kumpulan penyelesaian. Data yang diperoleh dari pakar diolah untuk mendapatkan nilai kinerja dan tingkat risiko.

\section{Hasil dan Pembahasan}

\section{Analisis Kebutuhan Pemangku Kepentingan}

Analisis kebutuhan para pemangku kepentingan dilakukan berdasarkan ukuran kepuasan dan kontribusi oleh Neely et al. [18]. Analisis dilakukan dengan merujuk pada naskah akhir interpretasi nasional prinsip dan kriteria untuk produksi minyak sawit berkelanjutan Republik Indonesia atau Roundtable on Sustainable Palm Oil Indonesian National Interpretation Working Group (RSPO INA-NIWG). Secara umum stakehoders satisfaction sebagai berikut:

Konsumen (Fast, Right, Cheap, Easy): Kualitas CPO (sustainable CPO). Harga yang kompetitif. Kemudahan dalam administrasi.

Employee (Purpose, Care, Skill, Pay): Pemberian upah yang sesuai atau paling tidak memenuhi standar minimum industri atau hukum, dan cukup untuk memenuhi kebutuhan dasar pekerja (kriteria 6.5). Tersedia fasilitas perumahan, air bersih, kesehatan, pendidikan dan kesejahteraan yang memadai (kriteria 6.5). Diperbolehkan adanya serikat kerja dan hak untuk berkumpul dan mengeluarkan pendapat (kriteria 6.6). Perusahaan tidak terlibat atau mendukung diskriminasi berbasis ras, kasta, kebangsaan, agama, ketidakmampuan fisik, jender, orientasi seksual, keanggotaan serikat, afiliasi politik atau umur (kriteria 6.8). Pencegahan pelecehan seksual dan berbagai bentuk kekerasan terhadap perempuan dan untuk melindungi hak reproduksi mereka dikembangkan dan diaplikasikan di lingkungan kerja (kriteria 6.9). Jaminan kesehatan dan keselamatan kerja (kriteria 4.7). Pelatihan skill karyawan untuk bekerja dan menyelamatkan diri (kriteria 4.8).

Investor berupa return, reward, figures, faith (Prinsip 3): Peningkatan keuntungan. Peningkatan skill karyawan. Minimasi biaya operasional. Kemudahan pengawasan dan perkembangan usaha (seluruh hasil terukur didokumentasikan dengan baik). Perbaikan terus-menerus pada wilayah-wilayah utama aktifitas (kriteria 8.1).

Supplier (Profit, Growth, Opinion, Trust): Perkebunan dan pabrik berurusan adil dan transparan (kriteria 6.10). Pembayaran tepat waktu. Administrasi yang mudah. Kelangsungan kerjasama yang baik.
Regulator (Legal, Fair, Safe, True): Pemenuhan terhadap seluruh persyaratan hukum yang berlaku yang mencakup peraturan tentang penguasaan tanah dan hak atas tanah, tenaga kerja, praktekpraktek pertanian (misalnya penggunaan pestisida atau bahan-bahan kimia), lingkungan (misalnya UU tentang satwa liar, polusi, pengelolaan lingkungan, dan kehutanan), tempat penyimpanan, transportasi dan proses pengolahan, perundang-undangan yang dikeluarkan di bawah UU atau konvensi internasional misalnya Konvensi Keanekaragaman Hayati, CBD (Prinsip 2). Memberi citra positif.

Masyarakat: Kontribusi terhadap pembangunan masyarakat lokal (kriteria 6.11). Adanya transparansi data, komunikasi, konsultasi, sistem penanggapan keluhan, prosedur kompensasi dan negosiasi (kriteria 6.2, 6.3, 6.4).

Selanjutnya, analisis terhadap stakeholders contribution dapat diuraikan sebagai berikut:

Konsumen (Profit, Growth, Opinion, Trust): Memberikan keuntungan berupa profit bagi perusahaan. Membantu mempromosikan perusahaan terkait sustainable.

Employee (Hands, Hearths, Minds, Voice): Melakukan pelayanan informasi kepada stakeholder berkaitan isu lingkungan, sosial, dan hukum (kriteria 1.1 dan 1.2). Melakukan rencana replanting tahunan untuk minimum 5 tahun ke depan yang setiap tahun dilakukan kaji ulang (kriteria 3.1). Mendokumentasikan prosedur operasi kebun dan pabrik (kriteria 4.1). Melakukan praktek mempertahankan dan meningkatkan kesuburan tanah (kriteria 4.2). Melakukan meminimalisasi dan mengendalikan erosi dan degradasi tanah (kriteria 4.3). Mempertahankan kualitas dan ketersediaan air permukaan dan air tanah (kriteria 4.4). Menerapkan teknik Pengendalian Hama Terpadu atau PHT (kriteria 4.5). Mengurangi/mencegah dampak negatif dan mendorong dampak positif (kriteria 5.1). Mengidentifikasi spesies langka, terancam dan hampir punah dengan nilai konversi tinggi (kriteria 5.2). Mengurangi, mendaur ulang dan membuang limbah dengan cara yang tepat (kriteria 5.3). Efisiensi energi dan memaksimalkan penggunaan energi terbarukan (kriteria 5.4). Menghindari penggunaan api untuk pemusnahan limbah atau pembukaan lahan (kriteria 5.5). Mengurangi pencemaran dan emisi, termasuk gas rumah kaca (kriteria 5.6).

Investor (Capital, Credit, Risk, Support): Menyediakan modal. Memperhatikan perkembangan usaha. Menyediakan lapangan kerja. 
Tabel 2. Struktur indikator-indikator risiko

\begin{tabular}{|c|c|}
\hline Aspek & Indikator-indikator \\
\hline Ekonomis & $\begin{array}{l}\text { E1. Volume permintaan } \\
\text { E2. Harga minyak sawit mentah } \\
\text { E3. Harga tandan buah segar } \\
\text { E4. Kualitas minyak sawit mentah } \\
\text { E5. Ketepatan jadwal pengiriman } \\
\text { minyak sawit } \\
\text { E6. Ketersediaan minyak sawit } \\
\text { mentah } \\
\text { E7. Losses } \\
\text { E8. Biaya pengolahan } \\
\text { E9. Distorsi informasi permintaan }\end{array}$ \\
\hline Lingkungan & $\begin{array}{l}\text { L1. Konsumsi energi } \\
\text { L2. Pengolahan limbah bernilai } \\
\text { tambah } \\
\text { L3. Reuse and recycle material } \\
\text { L4. Ancaman bencana alam } \\
\text { L5. Remanufacturing } \\
\text { L6. Kualitas lahan } \\
\text { L7. Penerapan teknologi ramah } \\
\text { lingkungan non-pengolahan }\end{array}$ \\
\hline Sosial & $\begin{array}{l}\text { S1. Mogok kerja buruh } \\
\text { S2. Unjuk rasa masyarakat } \\
\text { S3. Perundangan lingkungan hidup } \\
\text { S4. Budaya lokal } \\
\text { S5. Serangan kriminal }\end{array}$ \\
\hline
\end{tabular}

Supplier (Fast, Right, Cheap, Easy): Melakukan pengiriman tepat waktu. Komitmen terhadap kualitas. Regulator (Rules, Reason, Clarity, Advise): Mendapatkan perlindungan keamanan dalam menjalankan usaha. Ketepatan waktu dalam pengajuan permohonan perijinan. Melakukan pengecekan terhadap pemenuhan hukum.

Masyarakat: Menjaga keamanan lingkungan sekitar perusahaan. Mempromosikan kepedulian sosial perusahaan.

\section{Model Pengukuran Kinerja}

Analisis kebutuhan para pemangku kepentingan dapat diformulasikan menjadi kumpulan indikator yang diperlukan dalam penilaian risiko dan pengukuran kinerja. Indikator-indikator diformulasikan berdasarkan tiga aspek yaitu ekonomis, lingkungan dan social. Hasil formulasi indikator-indikator dapat dilihat pada Tabel 2.

Ada dua jenis ukuran kinerja yang diformulasikan yaitu kinerja parsial dan kinerja keseluruhan berdasarkan key performance indicators (KPI). Adapun formulasi matematika untuk kedua jenis ukuran kinerja sebagai berikut:

$P P_{i}=\sum_{j} w_{i j} \cdot s_{i j} \quad \forall i$

$T P=\sum_{i} \sum_{j} w_{i j} \cdot s_{i j} \quad \forall i \forall j$
Notasi sebagai berikut:

$P P_{i}$ : ukuran kinerja parsial (partial performance) untuk obyektif ke- $i$

TP : ukuran kinerja total (total performance)

$w_{i j}$ : bobot (weight) untuk KPI ke- $j$ dan obyektif ke- $i$

$s_{i j}:$ skor untuk KPI ke-j dan obyektif ke- $i$

$i \quad$ : indeks untuk obyektif

$j \quad$ : indeks untuk KPI

Formulasi penentuan ukuran kinerja dapat diselesaikan menggunakan algoritma komputasi sebagai berikut:

Tetapkan bobot dan capaian dari setiap indikator. Hitung nilai score untuk setiap KPI untuk periode $t$ dan simpan dalam database.

Hitung pencapaian setiap KPI dengan cara membandingkan capaian dengan target yang telah ditetapkan. Simpan hasil di dalam database. Dapatkan score untuk setiap indikator berdasarkan interval capaian yang telah ditetapkan. Simpan di dalam database.

Hitung $P P_{i}$ untuk periode $t$ dan simpan dalam database. Panggil bobot untuk setiap KPI dari obyektif ke $i$. Panggil skor untuk setiap KPI dari obyektif ke $i$. Hitung hasil kali $w_{i j}$ dan $s_{i j}$ untuk $j$. Jumlahkan hasil kali. Simpan di database.

Hitung TP untuk periode $\mathrm{t}$ dan simpan dalam database. Panggil bobot setiap KPI dari database. Panggil $P P_{i}$ dari database. Hitung hasil kali $w_{i j}$ dan $s_{i j}$ untuk $i$. Simpan di dalam database.

Ulangi perhitungan pencapaian setiap KPI jika bobot KPI dan obyektif tidak berubah. Jika tidak, maka tetapkan bobot dan capaian dari setiap indikator.

\section{Model Penilaian Risiko}

Teknik penilaian risiko yang dikembangkan terdiri dari dua bagian, pertama adalah penilaian kemungkinan risiko dan kedua adalah penilaian terhadap dampak atau kekerasan risiko. Agregasi tingkat risiko adalah perkalian antara kemungkinan risiko dan kekerasan risiko. Algoritma dikembangkan berdasarkan operator ordered weighted average oleh Yager [34]. Rumusan algoritma sebagai berikut:

Tetapkan banyak pakar penilai risiko $(r)$ dan banyak titik-titik skala penilaian $(q)$ dimana $r=1,2, \ldots, m ; q=1,2 \ldots, n$. Selanjutnya Berikan penilaian kemungkinan risiko oleh setiap pakar $k=1,2, \ldots, r$ untuk seluruh pemicu risiko $i$. Berikan 
penilaian dampak risiko oleh setiap pakar $k$ untuk seluruh pemicu risiko $i$.

Hitung nilai agregasi dari seluruh pakar untuk kemungkinan risiko dan dampak risiko untuk setiap pemicu risiko. Langkah-langkah agregasi nilai sebagai berikut:

Lakukan reordering nilai-nilai berdasarkan nilai skala tertinggi ke skala terendah, $B(j)$ untuk setiap indikator ke-j dimana $j=1,2, \ldots, r$.

Definisikan fungsi perataan aritmatik $Q_{A}(j)$ untuk setiap indikator $j$ menggunakan:

$Q_{A}(j)=$ Intejer $\left[1+k \frac{q-1}{r}\right]$

Bandingkan $Q_{A}(j)$ dan $B(j)$. Pilih nilai minimum. Dapatkan nilai agregasi yaitu

$\operatorname{Max}\left[\operatorname{Min}\left\{Q_{A}(j), B(j)\right\}\right]$ untuk setiap $j=1,2, \ldots, r$

Ulangi proses agregasi ini untuk mendapatkan nilai agregasi tingkat faktor.

Tempatkan nilai agregasi kemungkinan risiko setiap faktor-faktor risiko sebagai $P_{i}$ dan dampak risiko dari setiap faktor-faktor risiko sebagai $I_{i}$. Tetapkan negasi dari $I_{i}$ sebagai $\operatorname{Neg}\left(I_{i}\right)$. Dapatkan nilai agregasi akhir sebagai $\operatorname{Min}\left[\operatorname{Max}\left\{\operatorname{Neg}\left(I_{i}\right), P_{i}\right\}\right]$

\section{Rekomendasi Pengelolaan Risiko}

Tingkat risiko yang diperoleh dari hasil penilaian akan ditindak lanjuti sebagai rencana aksi. Studi ini menggunakan hasil studi sebelumnya oleh Haryana et al. [11] yang telah merumuskan kebijakan dan strategi berkelanjutan industri kelapa sawit di Indonesia. Rumusan tersebut dirujuk sebagai basis pengetahuan dalam model yang dikembangkan. Basis pengetahuan ini dipandang sebagai kumpulan penyelesaian layak dasar (basic feasible solutions). Kumpulan penyelesaian sebagai berikut:

P1. Pembentukan klaster industri kelapa sawit.

P2. Pengembangan jaringan infrastruktur secara terintegrasi.

P3. Insentif fiskal bea masuk untuk peralatan dan mesin-mesin.

P4. Alokasi kredit bersubsidi bunga untuk investasi dan modal kerja pengembangan industri hilir.

P5. Insentif bea keluar untuk ekspor produk hilir dan produk samping.

P6. Disinsentif bea keluar untuk ekspor bahan mentah dengan tetap memperhatikan keberadaan industri hulu.

P7. Pemberian disinsentif diberlakukan terhadap pelanggar kelapa sawit berkelanjutan.

P8. Peningkatan anggaran dan investasi litbang.
P9. Kerjasama penelitian dan pengembangan antara pemerintah, swasta dan lembaga penelitian termasuk perguruan tinggi.

P10. Perumusan agenda riset pengembangan komoditas kelapa sawit untuk memenuhi kebutuhan pangan (minyak goreng), pakan, bahan bakar dan serat, penelitian pengembangan daya saing.

P11. Penyediaan dan pemberian informasi oleh lembaga-lembaga pemerintah pusat dan daerah tentang perkebunan dan industri pengolahan kelapa sawit.

P12. Respon kebijakan kontra kampanye negatif terhadap kelapa sawit dengan memanfaatkan fakta dan hasil penelitian tentang kelapa sawit.

P13. Meningkatkan intensitas promosi dan advokasi dalam menghadapi kampanye negatif terhadap kelapa sawit.

P14. Menggunakan Indonesian Sustainable Palm Oil (ISPO) sebagai alat promosi, advokasi dan kampanye publik untuk memperkuat posisi tawar kelapa sawit Indonesia.

P15. Sosialisasi dan pelatihan penerapan prinsip dan kriteria berkelanjutan terutama kepada petani.

P16. Monitoring dan evaluasi penerapan prinsip dan kriteria berkelanjutan.

P17. Fasilitasi promosi, advokasi dan kampanye positif bahwa pembangunan perkebunan di Indonesia telah menerapkan prinsip dan kriteria pembangunan kelapa sawit berkelanjutan.

P18. Kerjasama kemitraan antara perusahaan perkebunan dan industri pengolahan kelapa dengan masyarakat sekitar/petani untuk mengembangkan perkebunan rakyat.

P19. Penguatan SDM bidang kelembagaan petani, baik dari pihak petani maupun perusahaan.

P20. Modifikasi program revitalisasi perkebunan kelapa sawit melalui penyediaan fasilitas kredit tanpa jaminan, terutama untuk peremajaan perkebunan kelapa sawit rakyat.

P21. Pemberian subsidi bunga sehingga tingkat bunga kredit menjadi murah dan terjangkau oleh petani.

P22. Penyediaan tenaga pendamping dalam penerapan inovasi teknologi dan kelembagaan.

P23. Penyediaan lahan bagi petani untuk menguasai lahan-lahan terlantar atau lahan lain sesuai ketentuan perundang-undangan yang berlaku.

P24. Pemberdayaan dan penguatan kelembagaan petani sehingga kelembagaan petani mempunyai status hukum yang pasti.

P25. Sosialisasi dan pelatihan kepada petani tentang penerapan berbagai teknologi, termasuk tentang bibit palsu, dalam rangka pembangunan kelapa sawit berkelanjutan.

P26. Penerapan model peremajaan kelapa sawit yang telah memperhitungkan kebutuhan tek- 
nologi, modal dan manajemen peremajaan terutama bagi perkebunan kelapa sawit rakyat.

P27. Pengembangan layanan penunjang agribisnis kelapa sawit, seperti penyediaan teknologi, sarana produksi (pupuk organik dan nonorganik serta obat-obatan) dan prasarana (alat dan mesin), serta informasi agribisnis terutama bagi perkebunan kelapa sawit rakyat.

P28. Penerapan kerjasama kemitraan antara lembaga petani dan perusahaan yang efektif dan berkeadilan sesuai ketentuan peraturan perundang-undangan yang berlaku (UU Kemitraan, UU Larangan Praktek Monopoli dan Persaingan Tidak Sehat dan Aturan-aturan Pelaksanaannya).

P29. Fasilitasi pengembangan kelembagaan petani melalui pertumbuhan dari bawah dan mampu menampung kepentingan para petani anggotanya dan pengembangan kegiatan usaha.

P30. Pengembangan sistem manajemen penerapan hukum dan perizinan pembangunan kelapa sawit berkelanjutan dengan menerapkan indikator dan persyaratan yang jelas dan tertib.

P31. Percepatan padu serasi antara Tata Guna Hutan Kesepakatan (TGHK) dengan Rencana Tata Ruang dan Wilayah (RTRW) semua tingkatan.

P32. Percepatan pelepasan kawasan hutan untuk hutan bagi areal penggunaan lain (APL) sesuai perundang-undangan yang berlaku termasuk moratorium hutan disertai penguatan hukum dalam implementasinya.

P33. Pemberian izin perluasan kebun diberlakukan untuk perusahaan yang menerapkan pembangunan berkelanjutan.

P34. Perluasan lahan hanya diijinkan bila produktivitas kebun sudah mencapai titik optimal.

P35. Perluasan dilakukan dengan memanfaatkan lahan pertanian terlantar.

\section{Kerangka Kerja Sistem}

Sistem beroperasi dengan prosedur menggunakan masukan non-numerik. Sistem ini menggunakan proses pengambilan keputusan berkelompok dengan pertimbangan bahwa perumusan kebijakan melibatkan beragam pihak. Pendekatan ini dianggap tepat untuk melakukan penilaian risiko berbasis kinerja. Sistem yang diusulkan ini berkemampuan memberikan penilaian operasional, taktis dan strategis. Kerangka kerja model terdiri dari beberapa langkah, yaitu:

Tetapkan banyak pemangku kepentingan yang dilibatkan dalam proses penilaian. Pemangku kepentingan inilah yang akan menilai bobot dampak risiko untuk setiap indikator. Selanjutnya proses komputasi untuk agregasi dampak risiko dapat dilakukan, sehingga setiap pemangku kepentingan dapat memberikan penilaian kinerja rantai pasok berdasarkan indikator-indikator yang telah ditetapkan. Lakukanlah proses komputasi untuk agregasi kinerja, proses komputasi untuk tingkat risiko dan proses basis aturan untuk penentuan kebijakan. Melalui hasil perhitungan tersebut maka rekomendasi kebijakan dapat diusulkan. Lakukan lagi penilaian kinerja rantai pasok oleh setiap pemangku kepentingan untuk periode penilaian berikutnya.

Kerangka kerja penilaian risiko berbasis kinerja yang diusulkan dapat memainkan peran penting dalam proses pembuatan kebijakan, antisipasi krisis dan deteksi dini. Sistem ini memungkinkan pemangku kepentingan untuk menavigasi sejumlah besar informasi secara cepat dan mengakomodir perbedaan pendapat antara berbagai pihak yang terlibat. Selain itu, sistem ini dapat mengeksplorasi keterkaitan antara faktor-faktor yang dapat mempengaruhi keputusan. Kerangka kerja dari sistem dapat dilihat pada Gambar 1.

\section{Analisis Risiko Rantai Pasok di Indonesia}

Kinerja rantai pasok minyak sawit berkelanjutan tidak terlepas dari kepentingan ekonomis. Menurut Manurung [17] jenis-jenis biaya pengelolaan perkebunan kelapa sawit merupakan penjumlahan dari semua pengeluaran dalam kurun waktu satu tahun tertentu, untuk melaksanakan kegiatan tertentu, sesuai dengan jadual pelaksanaan kegiatan. Biayabiaya yang harus dikeluarkan oleh perusahaan dalam pelaksanaan kegiatan proyek di antaranya adalah: (i) mendapatkan Hak Guna Usaha (HGU) lahan perkebunan kelapa sawit, (ii) investasi tanaman kelapa sawit, (iii) pemeliharaan tanaman, (iv) pemanenan TBS, (v) pemupukan, (vi) pengangkutan TBS ke pabrik pengolahan, (vii) investasi pembangunan pabrik, (viii) biaya pengolahan TBS menjadi CPO dan KPO, (ix) biaya pengangkutan CPO dan KPO dari lokasi PKS ke pelabuhan ekspor, (x) biaya overhead, dan (xi) biaya depresiasi.

Rangkaian kegiatan rantai pasok memberikan kontribusi terhadap tiga aspek keberlanjutan. Tentunya, upaya peningkatan kinerja minyak sawit berkelanjutan dapat dievaluasi melalui kumpulan indikator. Hasil penilaian kinerja minyak sawit berkelanjutan dapat dilihat pada Tabel 3. Hasil penilaian diperoleh melalui pendapat para pakar baik yang terkait dengan capaian maupun standar penilaian. Aplikasi dari model yang dikembangkan dalam studi ini adalah manajemen rantai pasok secara makro. Model ini juga dapat diterapkan untuk sistem rantai pasok skala mikro misalnya manajemen rantai pasok pada perusahaan perkebunan kelapa sawit. Hasil dari kinerja pada Tabel 3 mencerminkan kinerja rantai pasok minyak sawit berkelanjutan di Indonesia. 


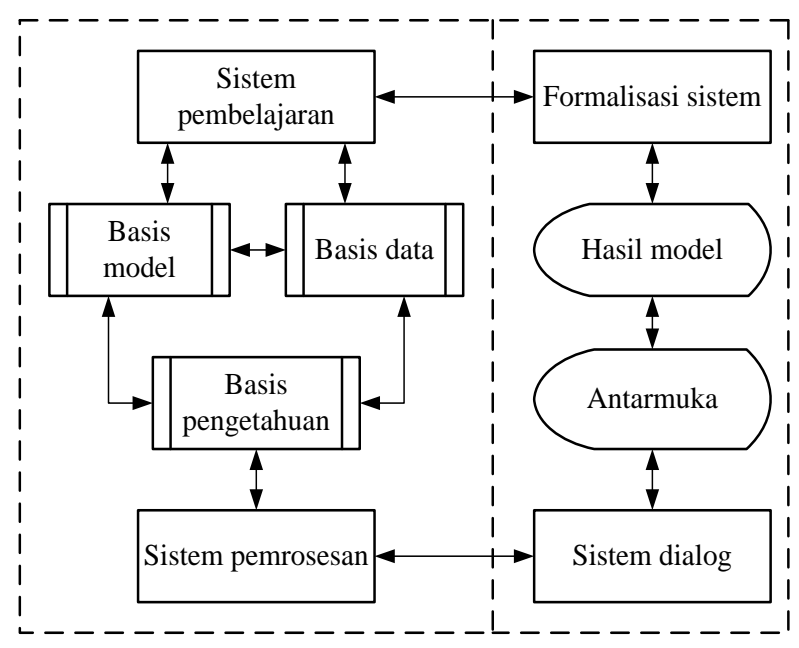

Gambar 1. Kerangka kerja sistem

Table 3. Kinerja minyak sawit berkelanjutan di Indonesia

\begin{tabular}{|c|c|c|}
\hline Aspek & Indikator-indikator & Kinerja \\
\hline \multirow{10}{*}{ Ekonomis } & Volume permintaan & Cukup baik \\
\hline & Harga minyak sawit & Biasa \\
\hline & Harga tandan buah & Biasa \\
\hline & Kualitas minyak sawit & Cukup baik \\
\hline & $\begin{array}{l}\text { mentah } \\
\text { Ketepatan jadwal }\end{array}$ & Cukup baik \\
\hline & $\begin{array}{l}\text { pengiriman minyak } \\
\text { sawit }\end{array}$ & \\
\hline & $\begin{array}{l}\text { Ketersediaan minyak } \\
\text { sawit mentah }\end{array}$ & Cukup baik \\
\hline & Losses & Biasa \\
\hline & Biaya pengolahan & Biasa \\
\hline & Efek bullwhip & Biasa \\
\hline \multirow{8}{*}{ Lingkungar } & Konsumsi energi & Biasa \\
\hline & $\begin{array}{l}\text { Pengolahan limbah } \\
\text { bernilai tambah }\end{array}$ & Biasa \\
\hline & Reuse and recycle & Biasa \\
\hline & material & \\
\hline & Ancaman bencana alam & Kurang baik \\
\hline & Remanufacturing & Biasa \\
\hline & Kualitas lahan & Biasa \\
\hline & $\begin{array}{l}\text { Penerapan teknologi } \\
\text { green non-pengolahan }\end{array}$ & Biasa \\
\hline \multirow{6}{*}{ Sosial } & Mogok kerja buruh & Biasa \\
\hline & Unjuk rasa masyarakat & Kurang baik \\
\hline & Perundangan & Biasa \\
\hline & lingkungan hidup & \\
\hline & Budaya lokal & Biasa \\
\hline & Serangan kriminal & Biasa \\
\hline
\end{tabular}

Proses pengukuran risiko dapat dilakukan dengan cara melihat potensial terjadinya seberapa besar severity (kerusakan) dan probabilitas terjadinya risiko tersebut. Penentuan probabilitas terjadinya suatu kejadian sangatlah subyektif dan lebih berdasarkan nalar dan pengalaman. Beberapa risiko memang mudah untuk diukur, namun sangatlah sulit untuk memastikan probabilitas suatu kejadian yang sangat jarang terjadi. Pada tahap ini sangat penting untuk menentukan dugaan yang terbaik supaya dapat dilakukan penentuan prioritas dengan baik. Kesulitan dalam pengukuran risiko adalah menentukan kemungkinan terjadi suatu risiko karena informasi statistik tidak selalu tersedia untuk beberapa risiko tertentu. Selain itu, mengevaluasi dampak severity (kerusakan) seringkali cukup sulit untuk asset intangible. Dampak adalah efek biaya, waktu dan kualitas yang dihasilkan suatu risiko. Penilaian dampak risiko keberlanjutan dari minyak sawit mentah di Indonesia dapat dilihat pada Tabel 4.

\section{Rekomendasi Kebijakan untuk Indonesia}

Pada dasarnya, pengelolaan industri minyak sawit mentah dapat dilakukan dengan kebijakan yang efektif baik secara ekonomis, ramah lingkungan dan sosial budaya. Lebih daripada itu, penciptaan peluang ekonomi dari minyak sawit berkelanjutan dapat mengentaskan masyarakat pedesaan dari kemiskinan. Hal ini dapat diyakini karena permintaan terhadap produk minyak sawit dunia akan terus mengalami peningkatan. Manfaat ekonomi yang diperoleh masyarakat dari pengusahaan kebun sawit menjadi efek berganda khususnya pengentasan kemiskinan. Menurut Syaukat [22], pengelolaan kebun yang lebih baik (better management of the plantation) mampu menekan dampak negatif lingkungan melalui pengolahan minyak sawit berkelanjutan dan keadilan sosial harus dijamin oleh Pemerintah.

Tabel 4. Tingkat risiko keberlanjutan

\begin{tabular}{ll}
\hline \multicolumn{1}{c}{ Indikator-indikator } & \multicolumn{1}{c}{ Risiko } \\
\hline Volume permintaan & Cukup besar \\
Harga minyak sawit mentah & Biasa \\
Harga tandan buah segar & Biasa \\
Kualitas minyak sawit mentah & Cukup besar \\
Ketepatan jadwal pengiriman & Cukup besar \\
minyak sawit & \\
Ketersediaan minyak sawit mentah & Cukup besar \\
Losses & Biasa \\
Biaya pengolahan & Biasa \\
Distorsi informasi permintaan & Cukup besar \\
Konsumsi energi & Biasa \\
Pengolahan limbah bernilai tambah & Biasa \\
Reuse and recycle material & Biasa \\
Bencana alam & Biasa \\
Remanufacturing & Biasa \\
Kualitas lahan & Biasa \\
Penerapan teknologi ramah & Biasa \\
lingkungan non-pengolahan & \\
Mogok kerja buruh & Biasa \\
Unjuk rasa masyarakat & Biasa \\
Perundangan lingkungan hidup & Biasa \\
Budaya lokal & Biasa \\
Serangan kriminal & Biasa \\
\hline &
\end{tabular}


Hasil penilaian risiko menunjukan bahwa beberapa indikator dari aspek ekonomis memberikan indikasi risiko cukup besar. Analisis kebijakan yang relevan untuk mengelola risiko beberapa indikator tersebut sebagai berikut:

Pengelolaan risiko untuk menjaga kinerja volume permintaan adalah: Pembentukan klaster industri kelapa sawit (P1). Pengembangan jaringan infrastruktur secara terintegrasi (P2). Insentif bea keluar untuk ekspor produk hilir dan produk samping (P5). Menggunakan Indonesian Sustainable Palm Oil (ISPO) sebagai alat promosi, advokasi dan kampanye publik untuk memperkuat posisi tawar kelapa sawit Indonesia (P14).

Pengelolaan risiko untuk menjaga kinerja kualitas minyak sawit adalah: Pemberian disinsentif diberlakukan terhadap pelanggar kelapa sawit berkelanjutan (P7). Kerjasama penelitian dan pengembangan antara pemerintah, swasta dan lembaga penelitian termasuk perguruan tinggi (P9). Penyediaan dan pemberian informasi oleh lembagalembaga pemerintah pusat dan daerah tentang perkebunan dan industri pengolahan kelapa sawit (P11). Meningkatkan intensitas promosi dan advokasi dalam menghadapi kampanye negatif terhadap kelapa sawit (P13). Menggunakan Indonesian Sustainable Palm Oil (ISPO) sebagai alat promosi, advokasi dan kampanye publik untuk memperkuat posisi tawar kelapa sawit Indonesia (P14).

Pengelolaan risiko untuk menjaga kinerja ketepatan jadwal pengiriman minyak sawit mentah kepada para konsumen adalah pengembangan jaringan infrastruktur secara terintegrasi (P2).

Pengelolaan risiko untuk menjaga kinerja ketersediaan minyak sawit mentah adalah: Pemberian subsidi bunga sehingga tingkat bunga kredit menjadi murah dan terjangkau oleh petani (P21). Penyediaan tenaga pendamping dalam penerapan inovasi teknologi dan kelembagaan (P22). Penyediaan lahan bagi petani untuk menguasai lahan-lahan terlantar atau lahan lain sesuai ketentuan perundang-undangan yang berlaku (P23). Pemberdayaan dan penguatan kelembagaan petani sehingga kelembagaan petani mempunyai status hukum yang pasti (P24). Sosialisasi dan pelatihan kepada petani tentang penerapan berbagai teknologi, termasuk tentang bibit palsu, dalam rangka pembangunan kelapa sawit berkelanjutan (P25). Penerapan model peremajaan kelapa sawit yang telah memperhitungkan kebutuhan teknologi, modal dan manajemen peremajaan terutama bagi perkebunan kelapa sawit rakyat (P26).

Pengelolaan risiko untuk mengurangi dampak distorsi informasi permintaan minyak sawit mentah adalah: Penyediaan dan pemberian informasi oleh lembaga-lembaga pemerintah pusat dan daerah tentang perkebunan dan industri pengolahan kelapa sawit (P11). Respon kebijakan kontra kampanye negatif terhadap kelapa sawit dengan memanfaatkan fakta dan hasil penelitian tentang kelapa sawit (P12).

\section{Simpulan}

Makalah ini memperkenalkan model penilaian risiko berbasis kinerja untuk rantai pasok yang sangat bermanfaat untuk perumusan strategi baik pada tingkat perusahaan maupun secara makro. Penerapan konsep ini telah dilakukan untuk manajemen rantai pasok minyak sawit berkelanjutan di Indonesia. Studi ini mengusulkan indikator-indikator kinerja yang bermanfaat dalam penerapan ISPO. Model yang telah jelaskan dalam makalah ini fokus menilai risiko berbasis kinerja rantai pasok minyak sawit mentah berkelanjutan di Indonesia pada tingkat makro. Keluaran dari model adalah nilai-nilai kinerja dan risiko dari setiap indikator keberlanjutan. Verifikasi model dilakukan dengan menganalisis kinerja dan risiko rantai pasok minyak sawit mentah berdasarkan bantuan analisis para pakar.

Aplikasi model menunjukan bahwa kinerja minyak sawit mentah berkelanjutan di Indonesia berada pada level biasa. Namun demikian, beberapa indikator dengan tingkat risiko cukup besar, yaitu volume permintaan, kualitas minyak sawit, ketepatan jadwal pengiriman, ketersediaan minyak sawit mentah dan distorsi informasi. Aplikasi model juga telah memberikan beberapa kebijakan untuk mengatasi risiko dari setiap indikator tersebut.

Ada dua hal yang dapat dilakukan untuk studi lanjutan, yaitu perancangan sistem penunjang keputusan yang user friendly dan penerapan konsep penilaian risiko berbasis kinerja untuk industri lainnya. Penerapan dapat dilakukan untuk skala mikro maupun makro. Langkah penting yang perlu diperhatikan dalam menerapkan konsep ini untuk industri lainnya adalah identifikasi indikator-indikator.

\section{Ucapan Terima Kasih}

Penulis mengucapkan terima kasih kepada Malaysia Institute of Transport (MITRANS) Universiti Teknologi MARA, Malaysia yang telah mendukung penelitian ini dan Emilda Sayuti dalam pengumpulan data. Penulis memberikan apresiasi kepada reviewer yang telah memberikan saran untuk penyempurnaan naskah awal. 


\section{Daftar Pustaka}

1. Beamon, B. M., Sustainability and Future of Supply Chain Management, Journal Operations and Supply Chain Management, 1(1), 2008, pp. 4-18.

2. Blengini, G. A., and Shields, D. J., Overview of the Building Products Supply Chain in Italy, Management of Environmental Quality: An International Journal, 21(4), 2010, pp. 477-493.

3. Carter, C., and Rogers, D. S., A Framework of Sustainable Supply Chain Management: Moving Toward New Theory, International Journal of Physical Distribution \& Logistics Management, 38(5), 2008, pp. 360-387.

4. Djohar S., Tanjung H., and Cahyadi, E. R., Building A Competitive Advantage on CPO Through Supply Chain Management: A Case Study in PT. Eka Dura Indonesia, Astra Agrolestari, Riau, Jurnal Manajemen \& Agribisnis, 1(1), 2003, pp. 20-32.

5. Faisal, M. N., Prioritization of Risks in Supply Chains, In: Managing Supply Chain Risk and Vulnerability: Tools and Methods for Supply Chain Decision Makers, editor Wu, T., and Blackhurst, J., Springer Publisher, 2009, pp. 4165.

6. Finke, G. R., Schmitt, A. J., and Singh, M., Modeling and Simulating Supply Chain Schedule Risk', Johansson, B., Jain, S., MontoyaTorres, J., Hugan, J., and Yücesan, E. (eds.), Proceedings of the 2010 Winter Simulation Conference, 2010, pp. 3472-3481.

7. Foerst, K., Reuter, C., Hartmann, E., and Blome, C., Managing Supplier Sustainability Risks in A Dynamically Changing Environment Sustainable Supplier Management in the Chemical Industry, Journal of Purchasing \& Supply Management, 16(2), 2010, pp. 118-130.

8. Hadiguna, R. A., Machfud, Eriyatno, Suryani, A., and Yandra., Manajemen Rantai Pasok Minyak Sawit Mentah, Journal Logistic and Supply Chain Management, 2(1), 2008, pp. 12-23.

9. Hadiguna, R. A., and Machfud, Model Perencanaan Produksi pada Rantai Pasok Crude Palm Oil dengan Mempertimbangkan Preferensi Pengambil Keputusan, Jurnal Teknik Industri, 10(1), 2008, pp. 38-49.

10. Hadiguna, R. A., Disain Penunjang Keputusan untuk Optimasi Persediaan Minyak Sawit Mentah dengan Pendekatan Logika Fuzzy, Proceeding Seminar on Application and Research in Industrial Technology (SMART), Yogyakarta, 2009, pp. A040-A045.

11. Haryana A., Indarto, J., and Avianto, N., Kebijakan dan Strategi dalam Meningkatkan Nilai Tambah dan Daya Saing Kelapa Sawit Indonesia secara Berkelanjutan dan Berkeadilan, Direktorat Pangan dan Pertanian, BAPPENAS. 2010.
12. Hahn, G. J., and Kuhn, H., Value-Based Performance and Risk Management in Supply Chains: A Robust Optimization Approach, International Journal of Production Economics, 2011, Doi: 10.1016/j.ijpe.2011.04.002

13. Jacxsens, L., Luning, P. A., van der Vorst, J. G. A. J., Devlieghere, F., Leemans, R., and Uyttendaele, M., Simulation Modelling and Risk Assessment as Tools to Identify the Impact of Climate Change on Microbiological Food SafetyThe Case Study of Fresh Produce Supply Chain, Food Research International, 43(7), 2010, pp. 1925-1935.

14. Khan, O., and Burnes, B., 'Risk and Supply Chain Management: Creating a Research Agenda, The International Journal of Logistics Management, 18(2), 2007, pp. 197-216.

15. Laeequddin, M., Sardana, G. D., Sahay, B. S., Waheed, K. A., and Sahay, V., Supply Chain Partners' Trust Building Process through Risk Evaluation: The Perspectives of UAE Packaged Food Industry, Supply Chain Management: An International Journal, 14(4), 2009, pp. 280-290.

16. Machfud, Eriyatno, Suryani, A., Yandra, and Hadiguna, R. A., Fuzzy Inventory Modelling of Crude Palm Oil in Port Bulk Tank, Jurnal Industri, 9(1), 2010, pp. 67-74.

17. Manurung, E. G. T., Analisis Valuasi Ekonomi Investasi Perkebunan Kelapa Sawit di Indonesia, US Agency for International Development, 2001.

18. Neely, A. D., Adams, C. A., and Kennerley, M., The Performance Prism the Scorecard for Measuring and Managing Busisness Success, New Jersey: Prentice Hall, 2003.

19. Sabri, E. H., and Beamon, B. M., A MultiObjective Approach to Simultaneous Strategic and Operational Planning in Supply Chain Design, OMEGA, 28(5), 2000, pp. 581-598.

20. Sarkis, J., A Strategic Decision Framework for Green Supply Chain Management, Journal of Cleaner Production, 11(4), 2003, pp. 397-409.

21. Scheller-Wolf, A., and Tayur, S., Risk Sharing in Supply Chains using Order Bands-Analytical Results and Managerial Insights, International Journal of Production Economics, 121(2), 2009, pp. 715-727.

22. Syaukat, Y., Menciptakan Daya Saing Ekonomi dan Lingkungan Industri Kelapa Sawit Indonesia, Agrimedia, 15(1), 2010, pp. 16-19.

23. Sikdar, S. K., Sustainable Development and Sustainability Metrics, The American Institute of Chemical Engineering Journal, 49(8), 2003, pp. 1928-1932.

24. Trkman, P., and McCormack, K., Supply Chain Risk in Turbulent Environments - A Conceptual Model for Managing Supply Chain Network Risk, International Journal of Production Economics, 119(2), 2009, pp. 247-258. 
25. Tang, C., Perspectives in Supply Chain Risk Management, International Journal of Production Economics, 103(2), 2006, pp. 451-488.

26. Vilko, J. P. P., and Hallikas, J. M., Risk Assessment in Multi Modal Supply Chains, International Journal of Production Economics, 2011.

27. Widodo, K. H., Sustainable Supply Chain Based Scenarios for Optimizing Trade-off between Indonesian Furniture and Crude-Palm-Oil Industries, Operations and Supply Chain Management, An International Journal, 3(3), 2010, pp. 176-185.

28. Wagner, B., and Svensson, G., Sustainable Supply Chain Practices: Research Propositions for the Future, International Journal of Logistics Economics and Globalisation, 2(2), 2010, pp. 176-186.

29. Widodo, K. H., Abdullah, A., and Arbita, K. P. D., Sistem Supply Chain Crude-Palm-Oil Indonesia dengan Mempertimbangkan Aspek Economical Revenue, Social Welfare dan Environment, Jurnal Teknik Industri, 12(1), 2010, pp. 47-54.
30. Weeks, K., Reverse Logistics Strategies as a Means to Improve Profitability, International Journal of Logistics Economics and Globalisation, 3(1), 2011, pp. 17-41.

31. Xia, D., and Chen, B., A Comprehensive Decision-Making Model for Risk Management of Supply Chain, Expert Systems with Applications, 38(4), 2011, pp. 4957-4966.

32. Yang, Z., and Li, J., Assessment of Green Supply Chain Risk Based on Circular Economy, IEEE 17Th International Conference on Industrial Engineering and Engineering Management (IE\&EM), 2010, pp. $1276-1280$.

33. Yeh, W. C., and Chuang, M. C., Using MultiObjective Genetic Algorithm for Partner Selection in Green Supply Chain Problems, Expert Systems with Applications, 38(4), 2011, pp. 4244-4253.

34. Yager, R. G., Non Numeric Multi Criteria Multi Person Decision Making, Group Decision and Negotiation, 2(1), 1993, pp. 81-93. 